about these incidents will be collected and evaluated centrally, and, where necessary, made available to other member states. The overall aim of the new system will be to improve the safety of patients, users, and others by seeking to prevent the same type of serious incident recurring elsewhere in the community.

These directives are intended greatly to simplify and harmonise the introduction of medical devices into both the European Community and, later, the countries of the European Free Trade Area. Naturally these new regulations introduce their own administrative difficulties and all players will need to apply common sense and sound judgment to avoid excessive bureaucracy. These procedures should, however, lead to advantages for both patients and doctors.

SUSANNE M LUDGATE

Senior medical officer

DON C POTTER

European and standards business manager

Medical Devices Directorate,

Department of Health,

London WC1B 5EP

\title{
Female genital mutilation
}

\section{Both the problem and the solutions rest with women}

Historically, female genital mutilation, also misleadingly known as female circumcision, has been protected under the veil of traditional practices considered to be too culturally sensitive to discuss. Female genital mutilation entails the total or partial cutting away of the female external genital organs with razors, ceremonial knives, or blades under non-hygienic conditions without anaesthesia. It is usually performed on girls ranging in age from 1 week to puberty.

Immediate physical complications include severe pain, shock, infection, injury to adjacent organs, broken bones, bleeding, acute urinary infection, tetanus, and death. Long term problems include chronic pain, difficulties with micturition and menstruation, pelvic infection leading to infertility, and prolonged and obstructed labour during childbirth. ${ }^{1}$

An estimated 80 million girls and women living today have undergone female genital mutilation, ${ }^{2}$ which is practised primarily in sub-Saharan Africa, the Arab world, Malaysia, and Indonesia and among migrant populations in Western countries. In Britain alone an estimated 10000 girls are currently at risk (E Dorkenoo and S Elworthy, first study conference of genital mutilation of girls in Europe, July 1993). Justification for the practice varies from region to region: religious, cultural, medical, and moral arguments have all been used. According to the World Health Organisation, the practice is closely associated with poverty, illiteracy, and the low status of women. Women who escape mutilation are stigmatised and are not sought in marriage, which helps explain the paradox that the victims of the practice are among the strongest proponents, along with traditional midwives, who perform the act. ${ }^{3}$

Many international agencies, including the World Health Organisation, the UN Population Fund, the UN Children's Fund, the International Planned Parenthood Federation, ${ }^{4}$ and the UN Convention on the Rights of the Child, have issued declarations advocating the eradication of female genital mutilation. Of importance to medical professionals around the world is a statement issued by WHO in 1982 that advised them not to perform female genital mutilation in any circumstances. Britain banned the practice in 1985 . While no convictions have been made in Britain, the legislation has resulted in intervention by local authorities to prevent parents from mutilating their daughters. ${ }^{5}$

In the countries where the practice is widespread education rather than legislation is seen as the way forward. In 1984 the Inter-African Committee Against Harmful Traditional Practices Affecting Women and Children was established to work towards eliminating female genital mutilation and other damaging customs such as marriage in early childhood, the preference for male children, and nutritional taboos for pregnant women. To date the committee has established national committees in 26 African countries. They support and coordinate projects, which are run by local people, supported by local authorities, and use traditional forms of communication such as theatre, dance, music, and story telling. ${ }^{6}$

During the past decade the topic has been discussed with greater openness by heads of state in Africa and the Arab world, international organisations, and non-government organisations. But more significantly, voices are being raised by the only people who can effectively challenge the practice-women whose health and lives have been seriously affected by female genital mutilation. And in Australia, Canada, Europe, and the United States women have organised to prevent the practice among vulnerable migrants and refugees in their countries. Women working at local level must be congratulated for their success in raising awareness about the severe threat to health of this practice. Empowering these women to define their needs and supporting their local networks is vital if international reform is to be achieved. International organisations, such as the United Nations, World Health Organisation, and International Planned Parenthood Federation, now have the opportunity to work at regional and international levels in support of women against female genital mutilation. By working together local women and international organisations will be most effective in eliminating this medical and humanitarian challenge to women's lives.

MALIKA LADJALI

Medical consultant TRACEY W RATTRAY International population fellow RUPERT J W WALDER Information officer

International Planned Parenthood Federation,

Regent's College,

London NW1 4 NS

1 Koso-Thomas O. The circumcision of women; a strategy for eradication. London: Zed Books, 1987. 2 Hosken F. Female circumcision: genital and sexual mutilation. Women's International Network News $1991 ; 17(4): 35$

3 World Health Organisation. Female genital mutilation. Geneva: WHO, 1993. (Press release WHA $/ 10$.)

4 International Planned Parenthood Federation. Statement on female genital mutilation, developed by IPPF international medical advisory panel. London: IPPF, 1991.

5 Dorkenoo E, Elworthy S. Female genital mutilation: proposals for change. London: Minority Rights Group International, 1992.

6 Inter-African Committee on Traditional Practices. Shon activity repons from LAC counterparts in Africa for the period 1987-1990. Prepared for the LAC conference in Addis Ababa, Ethiopa, November 1990. Addis Ababa: IAC, 1990 